\title{
Pengaruh Pencarian Sensasi dan Harga Diri Terhadap Sexting Behavior pada Remaja Pelaku Sexting Di Jakarta
}

\author{
FRISTMIA MANALU, M. RAMADHANA, SILVERIUS Y. SOEHARSO \\ Fakultas Psikologi, Universitas Pancasila
}

Email: rama.reksoprodjo@univpancasila.ac.id, sonny.soeharso@gmail.com

\begin{abstract}
Sexting behavior is an activity that is commonly practiced nowadays by teenagers. In this study, sexting behavior is defined as the activity of receiving, sending, receiving and sending sexual content like photos, text messages, or video via mobile phone. This study aims to determine the effect of sensation seeking and self-esteem on sexting behavior in adolescent in Jakarta. The study involved 370 male and female respondents with any backgrounds. The analysis technique used in this research is multiple regression, independent sample t-test and also ANOVA. Some of the results of this study indicates that: (1) there is influences of sensation seeking and self-esteem against sexting behavior, (2) there is influence of sensation seeking against sexting behavior, (3) there is no influence of selfesteem against sexting behavior, and (4) there is difference of sexting behavior in terms of age, education, and sexual orientation. From the results of the study also known that sexting behavior occurs in teenagers, regardless of sexual orientation, educational background, and status of respondents. While it is also known that the most widely referred figure as the purpose of sexting behavior is peers. The most frequent motivation for doing sexting behavior is an attempt to share and try to tease a friend or spouse.
\end{abstract}

Keywords: sexting behavior, sensation seeking, self-esteem, adolescents

Abstrak: Sexting behavior merupakan kegiatan yang lazim dilakukan para remaja sekarang ini. Pada penelitian ini, sexting behavior diartikan sebagai kegiatan menerima, mengirim, serta menerima sekaligus mengirim konten berkonotasi seksual berupa pesan teks, gambar atau foto dan video melalui ponsel. Penelitian ini bertujuan untuk mengetahui pengaruh pencarian sensasi dan harga diri terhadap sexting behavior pada remaja pelaku sexting di Jakarta. Penelitian ini melibatkan 370 responden lakilaki dan perempuan dengan latar belakang yang berbeda-beda. Teknik analisis yang digunakan dalam penelitian ini adalah regresi berganda dan uji beda dengan independent sample t-test maupun ANOVA. Beberapa hasil penelitian yang ditemukan adalah (1) pencarian sensasi dan harga diri berpengaruh secara signifikan terhadap sexting behavior, (2) pencarian sensasi berpengaruh terhadap sexting behavior, (3) harga diri tidak berpengaruh terhadap sexting behavior, (4) terhadap perbedaan sexting behavior ditinjau dari usia, pendidikan, dan orientasi seksual. Hasil penelitian juga menyiratkan bahwa sexting behavior merupakan perilaku yang biasa dilakukan oleh remaja, apapun orientasi seksual, latar belakang pendidikan, dan status responden. Sementara itu juga diketahui bahwa figur yang paling banyak disebut sebagai tujuan sexting behavior adalah teman sebaya. Adapun motivasi melakukan sexting behavior yang paling sering disebut adalah sekedar berbagi dan usaha untuk menggoda teman atau pasangan.

Kata Kunci: perilaku sexting, pencarian sensasi, harga diri, remaja

\section{PENDAHULUAN}

Salah satu sarana yang biasa digunakan remaja dan orang dewasa dalam berkomunikasi adalah internet. Internet digunakan untuk memperoleh berbagai informasi yang dibutuhkan. Di samping banyaknya informasi yang mudah diakses, ternyata internet dapat disalahgunakan (Bunardi, 2015). Hal ini terlihat dari maraknya 
peredaran konten berkonotasi seksual di dunia maya. Selama beberapa tahun terakhir ini, media berita di beberapa negara telah melaporkan banyaknya kasus anak di bawah umur (18 tahun) yang menggunakan kamera digital untuk memproduksi dan mendistribusikan gambar berkonotasi seksual (diri sendiri maupun orang lain), beberapa kasus diantaranya melanggar hukum pornografi (Lee \& Crofts, 2015).

Beberapa tahun setelahnya, kegiatan bertukar konten berkonotasi seksual terus mengalami peningkatan. Hal ini terbukti dengan adanya temuan baru dari Rahardjo, Hapsari, dan Saputra (2014) yang menyebutkan bahwa mahasiswa jenjang sarjana merupakan responden yang memiliki rata-rata skor kegiatan mengirim dan menerima konten berkonotasi seksual paling tinggi, dikarenakan mahasiswa memiliki waktu luang yang paling banyak dibandingkan kelompok partisipan lainnya (anak SMA dan D3). Selain itu, kegiatan tukar-menukar konten berkonotasi seksual semakin marak terjadi dikarenakan sejumlah aplikasi tertentu pada ponsel (seperti blackberry messenger, whatsapp, SMS, LINE, facebook, dan twitter) turut memudahkan individu untuk dapat mengirim dan menerima foto, video, share location maupun pesan teks.

Kegiatan tukar menukar konten berkonotasi seksual merupakan bagian dari aktivitas seksual. Shaughnessy, Byers, dan Walsh (2011) menyebutkan bahwa terdapat tiga aktivitas seksual, diantaranya mencari informasi seksual secara online, melihat pornografi online, serta berbagi fantasi seksual. Merujuk pada berbagai aktivitas seksual tersebut, Duncan (2010) menyebutkan pornografi anak (cybersex) sering diistilahkan media dengan sexting behavior. Di samping itu, Crofts, Lee, McGovern, dan Milivoievic (2017) turut menyebutkan sexting behavior merupakan salah satu bentuk dari cybersex yang diartikan sebagai kegiatan mengirim, menerima, dan membagikan konten berkonotasi seksual (berupa foto, video, pesan teks) melalui ponsel, jejaring sosial, dan lainnya (Lenhart, 2009; Weisskirch \& Delevi, 2011; Dir, Avca, Jennifer, \& Melissa, 2013; Scholes-Balog, Francke, \& Hemphill, 2016).

Di samping itu, sexting behavior dianggap sebagai perilaku menyimpang dari norma sosial dan hukum, tidak disetujui perbuatannya oleh masyarakat luas maupun pihak berwenang, lantaran menghasilkan respons kontrol sosial seperti teguran atau penolakan sosial (Dir dkk., 2013; Rahardjo dkk., 2014). Berdasarkan pernyataan tersebut, Polda Metro Jaya mencatat bahwa sepanjang tahun 2017 terdapat tiga kasus cybersex yang tersangkanya merupakan anak-anak di bawah umur yang berujung pada tindakan pidana, salah satunya adalah kasus DA. DA merekam video bugil korban, kemudian mengunggah video tersebut ke sosial media yang bisa dilihat oleh semua orang, karena perbuatannya tersebut, DA diberikan sanksi dari pihak yang berwenang (Asyari dalam Jawapos, 2017). Tidak sekedar kehilangan muka hingga akhirnya depresi dan melakukan bunuh diri, risiko pidana dapat dikenakan kepada para pelaku sexting behavior.

Selain memberi sanksi hukum kepada para pelakunya, Wolak, Finkelhor dan Mitchell (dalam Scholes-Balog dkk., 2016) menyebutkan konten berkonotasi seksual yang tersebar luas tanpa persetujuan dari 
pemilik/pembuat konten berpotensi menimbulkan dampak terhadap hubungan sosial, kesehatan emosional, pekerjaan, sekolah, hubungan berpacaran, serta berdampak serius pada hukum, jika mereka yang terlibat merupakan anak-anak di bawah umur (di bawah 18 tahun), ditambah lagi berpotensi menimbulkan gangguan kesehatan mental dan perilaku berisiko lainnya, seperti perilaku seksual berisiko.

Beberapa temuan di atas memperlihatkan mayoritas pelaku sexting behavior merupakan remaja dibandingkan dengan dewasa muda (Abeele, Scott, Steven, \& Keith, 2014). Hal ini terjadi dikarenakan pada masa ini, remaja memiliki rasa ingin tahu dan dorongan seksual yang cenderung meningkat, serta membutuhkan kepuasan seksual untuk mengejar afiliasi (Santrock, 2012). Berdasarkan hal tersebut, remaja semakin rentan terlibat sexting behavior. Rasa ingin tahu berkaitan dengan pengalaman individu dalam interaksi dan proses meniru dari role models (keluarga, pertemanan maupun significant others) selama hidupnya atau lebih dikenal dengan istilah teori belajar sosial dari Bandura (Akers \& Jennings, 2009).

Berkenaan dengan teori tersebut, diketahui terdapat beberapa motif yang melatarbelakangi remaja terlibat sexting behavior, yakni meningkatnya kesenangan dan kepuasan, adanya pengakuan dari temanteman sebaya, diperolehnya pasangan seksual, meningkatnya kualitas hubungan dengan pasangan, mengurangi risiko kemungkinan terkena penyakit menular seksual (IMS), serta sebagai usaha untuk menarik perhatian orang lain (Albury \& Crawford, 2012; Lippman \& Campbell, 2014; Van Ouytsel dkk., 2016;
Parker, Kristyn, Martha, \& Jillian, 2012; Walrave dkk., 2014).

Sejumlah penelitian telah membenarkan bahwa mereka yang sedang menjalani hubungan berpacaran dapat dengan mudah mengirimkan konten berkonotasi seksual dikarenakan mereka memiliki seseorang untuk berbagi. Atau dengan kata lain, sexting behavior disarankan untuk dilakukan bagi dua orang yang sedang menjalani hubungan berpacaran sebagai strategi pemeliharaan hubungan, atau merupakan bagian dari foreplay, serta dapat meningkatkan kualitas hubungan (Delevi \& Weisskirch, 2013; Weisskirch \& Delevi, 2011). Di sisi lain, keterlibatan remaja perempuan dengan sexting behavior dipengaruhi oleh adanya tekanan dari pasangan (Lee \& Crofts, 2013). Sementara itu, laki-laki dewasa bersaing satu sama lain untuk memperoleh sebanyak mungkin konten berkonotasi seksual dari perempuan dewasa sebagai 'piala kebesaran' untuk dapat dipamerkan kepada teman-temannya ataupun dijadikan bukti karena telah sukses menaklukkan seorang perempuan. Hal ini terjadi di berbagai budaya, seperti di Inggris (Ringrose, Harvey, Gill, \& Livingstone, 2013), Amerika Serikat (Lippman \& Campbell, 2012), dan Australia (Walker, Sanci \& Temple-Smith, 2013; Yeung, Horyniak, Vella, Hellard, \& Lim, 2014).

Terdapat sejumlah faktor lain yang mendorong terjadinya sexting behavior, yakni usia, jenis kelamin, pencarian sensasi, frekuensi menggunakan internet, status hubungan, harga diri, insomnia, kontrol diri, dan liburan panjang yang membosankan (Leung, 2008; Baumgartner, Sumter, Peter, 
Valkenburg, \& Livingstone, 2014; Hudson \& Fetro, 2015; Jenaro, Flores, Gomez-Vela, Gonzalez-Gil, \& Cabello, 2017; Lee, Moak, \& Walker, 2016; Van Ouytsel, Walrave, \& Van Gool, 2014; Rahardjo dkk., 2015; ScholesBalog dkk., 2016; Wachs, Wright, \& Wolf, 2017; The National Campaign's Sex \& Tech, 2008). Dari sekian banyak faktor yang telah disebutkan tadi, beberapa penelitian sebelumnya menyebutkan terdapat dua faktor dari dalam diri individu yang secara konsisten mempengaruhi sexting behavior, yakni pencarian sensasi (Baumgartner dkk., 2014; Van Ouytsel dkk., 2014) dan harga diri (The National Campaigns' Sex \& Tech, 2008; Scholes-Balog dkk., 2016).

Pencarian sensasi memegang peranan penting dalam diri tiap individu, dimana fungsi ciri kepribadian ini mulai berkembang pada usia 9 hingga 14 tahun, kemudian terus mengalami peningkatan pada masa remaja akhir atau dalam kisaran usia 20-an tahun, kemudian mulai menurun dan cenderung stabil di akhir usia dewasa muda. Pencarian sensasi turut mempengaruhi individu untuk mencari pengalaman yang sifatnya kompleks, intens, baru, sehingga individu cenderung terlibat dalam perilaku berisiko atau bermasalah (Zuckerman, 1979). Di dalam konteks sexting behavior, sejumlah penelitian menyebutkan bahwa pencarian sensasi berkaitan dengan perilaku ini. Remaja dengan pencarian sensasi yang tinggi biasanya mencari rangsangan dalam hidup mereka, dimana mereka mungkin mau mengirimkan konten berkonotasi seksual (pesan teks) karena mereka menyukai sesuatu yang sifatnya menyenangkan dan tidak mudah takut dengan konsekuensi negatif (Baumgartner dkk., 2014).
Di samping itu, Leung (2007) menyebutkan bahwa kecanduan akan penggunaan ponsel berpotensi meningkatkan pencarian sensasi pada diri remaja. Di dalam konteks sexting behavior, remaja terlihat memiliki keinginan untuk mencari informasi mengenai perilaku tersebut, mencari tahu keberadaan orang-orang yang juga terlibat melalui aplikasi jejaring sosial, serta melakukan pertukaran konten berkonotasi seksual tanpa memikirkan risiko atau dampak negatifnya. Hasil penelitian dari Van Ouytsel, dkk. (2014) juga menyebutkan remaja dengan usia yang lebih tua, serta memperoleh skor lebih tinggi dalam hal pencarian sensasi cenderung terlibat sexting behavior, dimana remaja cenderung menyukai pengalaman yang sifatnya mendebarkan dan mengundang sensasi tersendiri.

Hal serupa turut disebutkan oleh Baumgartner, dkk. (2014), yakni remaja dengan rasa ingin tahu yang besar didukung dengan penggunaan ponsel cenderung membuat remaja menstimulasi kehidupannya melalui berbagai aktivitas pencarian sensasi terhadap isu-isu tertentu yang menarik perhatian mereka, salah satunya adalah sexting behavior. Para remaja tersebut diketahui sering mengirimkan pesan teks berkonotasi seksual karena dilandasi perasaan senang ketika memperoleh pujian dari pasangannya maupun orang lain, dan remaja memiliki anggapan sexting behavior merupakan kegiatan yang aman untuk dilakukan karena tidak memberikan risiko atau dampak negatif secara langsung terhadap dirinya, serta menggunakan internet untuk melakukan sexting behavior. 
Sebahagian besar remaja beranggapan kemungkinan besar foto dan video berkonotasi seksual miliknya dapat tersebar luas tanpa persetujuan darinya. Konten berkonotasi seksual yang tersebar berpotensi digunakan sebagai alat untuk mempermalukan dirinya sendiri dimasa mendatang (Dir, Cyders, \& Coskunnpinar, 2013). Oleh karena itu, untuk mengurangi dampak negatif dari sexting behavior, remaja biasanya hanya mengirimkan konten berkonotasi seksual (pesan teks) pada pasangannya ataupun orang lain.

Selain itu, keinginan atau harapan yang dimediasi oleh pencarian sensasi yang tinggi melatarbelakangi lahirnya sexting behavior (Dir dkk., 2013). Misalnya remaja akan merasa lebih senang ketika mereka mampu melakukan perburuan konten berkonotasi seksual (dengan cara meminta kepada pasangan ataupun orang lain), serta merasa bangga ketika memperoleh pengakuan dari teman sebaya maupun pasangannya atas kemampuannya dalam menerima dan mengirimkan konten berkonotasi seksual.

Jika beberapa penelitian sebelumnya menyebutkan pencarian sensasi memiliki pengaruh terhadap sexting behavior, berbeda dengan hasil penelitian yang ditunjukkan Delevi dan Weisskirch (2013), yakni pencarian sensasi tidak muncul sebagai prediktor sexting behavior dalam hal mengirimkan foto atau pesan teks berkonotasi seksual pada pasangan maupun orang lain. Hal ini dikarenakan sexting behavior dianggap tidak cukup memberikan pengalaman yang sifatnya baru kepada individu dengan pencarian sensasi tinggi. Bisa juga diartikan sexting behavior telah diterima secara kultural di kalangan remaja maupun orang dewasa, dimana perilaku ini tidak dianggap berisiko, tetapi dipandang normatif sebagai tindakan untuk meningkatkan kualitas hubungan. Ditambah lagi, keyakinan yang dimiliki oleh remaja yang menyebutkan pasangan maupun orang lain akan melakukan hal itu terhadap dirinya, sehingga remaja merasa tidak perlu bersusah payah untuk memperoleh konten berkonotasi seksual.

Selain pencarian sensasi, faktor lain yang mempengaruhi sexting behavior adalah harga diri. Beberapa penelitian sebelumnya menyebutkan bahwa harga diri memiliki pengaruh terhadap sexting behavior pada remaja. Duncan (2010) menyebutkan penilaian positif (percaya diri yang tinggi) terhadap tubuh mampu membuat remaja terlibat sexting behavior, hal ini terlihat dari keberanian remaja dalam memamerkan konten berkonotasi seksual miliknya. Berkebalikan dengan hasil penelitian dari Scholes-Balog, Francke, dan Hemphill (2016) yang menyebutkan harga diri yang tinggi cenderung mengurangi keterlibatan remaja dalam sexting behavior, dimana keyakinan diri akan dampak negatif didukung dengan penilaian diri positif membuat remaja berpikir dua kali untuk mengirimkan foto telanjang miliknya.

The National Campaigns' Sex \& Tech (2008) menemukan dua hal terkait harga diri dan sexting behavior. Pertama, penilaian diri yang positif cenderung membuat remaja semakin terlibat sexting behavior, hal ini dikarenakan mereka memiliki keberanian serta rasa percaya diri untuk mengirimkan konten berkonotasi seksual kepada orang lain. Kedua, penilaian diri negatif (putus asa dan tidak aman) cenderung membuat remaja semakin terlibat sexting behavior. Hal ini terjadi karena 
individu mendasarkan harga diri mereka pada opini dan reaksi dari teman sebaya (Harter dalam Guindon, 2010). Demi memperoleh pengakuan dari pasangan maupun teman sebaya, remaja menjadi sulit untuk mengendalikan dirinya ketika dihadapkan pada situasi yang penuh dengan rangsangan seksual, sehingga cenderung mengambil keputusan berdasarkan perasaannya saat itu, tanpa berpikir panjang atas akibat yang mungkin akan terjadi sehingga memberi dampak negatif bagi dirinya sendiri.

Jika beberapa penelitian sebelumnya menyebutkan sexting behavior dipengaruhi oleh harga diri, dua penelitian lainnya menemukan tidak terdapat pengaruh harga diri terhadap sexting behavior. Gordon-Messer, Bauermeister, Grodzinski, dan Zimmerman (2013) tidak menemukan perbedaan tingkatan harga diri (baik tinggi maupun rendah) pada dalam hal mengirim, serta menerima sekaligus mengirimkan konten berkonotasi seksual. Serupa dengan hal itu, hasil penelitian dari Vanden, Roe dan Eggermont pada tahun 2012 menyebutkan harga diri tidak memiliki pengaruh terhadap sexting behavior pada remaja terkait dengan kegiatan tukar menukar konten berkonotasi seksual melalui ponsel.

Berdasarkan penjabaran di atas, maka penelitian ini ingin membuktikan ada atau tidaknya pengaruh pencarian sensasi dan harga diri terhadap sexting behavior pada remaja, hal ini dikarenakan penelitian mengenai sexting behavior masih sedikit dibahas di Indonesia. Adapun remaja yang dimaksudkan dalam penelitian ini memiliki rentang usia 11 hingga 20 tahun (Papalia \& Martorell, 2017), aktif menggunakan aplikasi whatsapp dan LINE untuk melihat keterlibatan mereka dalam sexting behavior. Oleh karena itu, penelitian ini ingin melihat "pengaruh pencarian sensasi dan harga diri terhadap sexting behavior pada remaja pelaku sexting di Jakarta".

\section{METODE}

Skala penelitian dalam bentuk angket disebarkan dengan teknik accidental sampling kepada responden dengan kriteria yang telah ditetapkan. Adapun kriteria responden dalam penelitian ini memiliki rentang usia antara 11 hingga 20 tahun, berdomisili di Jakarta, serta memiliki dan aktif menggunakan aplikasi whatsapp dan LINE.

Alat ukur yang digunakan untuk mengukur sexting behavior diadaptasi dari Sexting Behavior Questionnaire (SBQ) yang dirancang oleh Rahardjo, Hapsari, dan Saputra (2014), yang disusun berdasarkan konsep milik Gordon-Messer, dkk. (2013). Alat ukur ini terdiri atas 8 pernyataan dan memiliki nilai reliabilitas yang baik sebesar 0.92, serta digunakan untuk melihat sexting behavior pada remaja.

Alat ukur yang digunakan untuk mengukur pencarian sensasi (sensation seeking) diadaptasi dan dimodifikasi dari alat ukur Sensation Seeking Scale Form $V$ milik Zuckerman (1979). Alat ukur ini terdiri atas 20 pernyataan (10 pernyataan favorable, 10 pernyataan unfavorable) yang disesuaikan dengan konteks sexting behavior, serta terdiri atas empat dimensi, yakni thrill and adventure seeking (TAS), experience seeking (ES), disinhibition (DS), dan boredom suscepteibility (BS). 
HASIL

Berdasarkan hasil uji hipotesis yang telah dilakukan dalam penelitian ini, diketahui terdapat pengaruh yang signifikan antara pencarian sensasi dan harga diri terhadap sexting behavior dengan nilai signifikan sebesar 0,000 .

Selain itu, proporsi varians IV terhadap DV adalah sebesar 0,389 atau 38,9\%, artinya pencarian sensasi dan harga diri memiliki pengaruh terhadap sexting behavior sebesar $38,9 \%$ dan sisanya $61,1 \%$ dipengaruhi oleh faktor lain di luar penelitian ini. Secara terpisah, pencarian sensasi diketahui memiliki pengaruh yang signifikan terhadap sexting behavior sebesar $66,3 \%$, sedangkan tingkatan harga diri diketahui tidak memiliki pengaruh terhadap sexting behavior.

\section{KESIMPULAN}

Sexting behavior diketahui belum memberi dampak negatif terhadap para responden. Di samping itu, berdasarkan hasil penelitian, sexting behavior diketahui dipengaruhi oleh pencarian sensasi. Hal ini memperlihatkan faktor internal seperti pencarian sensasi sangat dipengaruhi oleh faktor biologi atau dorongan seksual memiliki peran yang lebih besar dalam perilaku ini.

\section{DISKUSI}

Sexting behavior telah banyak menarik perhatian media maupun masyarakat luas di berbagai negara selama beberapa tahun terakhir ini, namun mayoritas penelitian lebih sering dilakukan di sejumlah negara Barat, seperti di Eropa dan Amerika Serikat.
Dikarenakan penelitian mengenai sexting behavior sangat sedikit dibahas di Indonesia, maka pengetahuan mengenai sexting behavior pada penelitian ini didasarkan pada hasil penelitian yang telah dilakukan oleh sejumlah ahli dari beberapa negara tersebut. Tujuan dilakukannya penelitian ini adalah untuk memperluas pemahaman mengenai pengaruh pencarian sensasi dan harga diri terhadap sexting behavior pada remaja (11 hingga 20 tahun) di kota Jakarta.

Berdasarkan hasil penelitian ini, terdapat beberapa hal yang dapat dipaparkan. Penelitian menunjukkan pencarian sensasi sering membuat remaja berani mengambil risiko hanya untuk menikmati pengalaman baru (Zuckerman, 1994). Namun, dampak negatif bukanlah sumber utama remaja yang memiliki pencarian sensasi tinggi, melainkan sebahagian besar remaja yang memiliki pencarian sensasi tinggi berusaha meminimalkan risiko atau dampak negatif dengan melakukan tindakan pencegahan (Zuckerman, 1991). Dengan demikian, remaja yang memiliki sensasi tinggi lebih memilih untuk terlibat sexting behavior berbasis konten milik orang lain. Namun dalam penelitian ini tidak diketahui darimana konten berkonotasi seksual berasal, apakah milik sendiri atau orang lain.

Remaja dengan pencarian sensasi yang tinggi dalam penelitian ini menyebutkan mereka tidak merasakan takut ketika mengirimkan konten berkonotasi seksual dan mengganggap perilaku ini menyenangkan untuk dilakukan. Hasil serupa turut disebutkan oleh Baumgartner, dkk. (2014).

Hal ini turut didukung dengan tersedianya fitur tertentu pada aplikasi yang 
terdapat pada ponsel, seperti whatsapp dan LINE yang diketahui memiliki sejumlah fitur berkualitas yang dapat membuat individu semakin terlibat sexting behavior, yakni kemudahan dalam mengambil dan membagikan foto, pesan teks, maupun video kepada orang lain yang juga menggunakan aplikasi yang sama, serta mudah dilakukan dimana saja dan kapan saja.

Selain itu, kedua aplikasi tersebut turut membantu individu untuk membentuk OA atau multichat dengan siapa saja. Hasil ini sesuai dengan penelitian yang dilakukan Rahardjo, Hapsari, dan Saputra (2014) yang menyebutkan remaja maupun dewasa melakukan sexting behavior melalui aplikasi BBM, whatsapp, pesan singkat (SMS), LINE, facebook, \& twitter.

\section{DAFTAR PUSTAKA}

Abeele, M. V., Scott W. C., Steven, E., \&Keith, R. (2014). Sexting, mobile porn use, \& peer group dynamics: boys and girls' self-perceived popularity, need for popularity, and perceived peer pressure. Media Psychology, 17, 6-33. doi: 10.1080/15213269.2013.801725

Akers, R. L., \& Jennings, W.G. (2009). The social learning theory of crime and deviance. In M. Krohn, A. Lizotte, \& G. Hall (Eds.). Handbook on Criminology and Deviance, 103-120. New York: Springer.

Albury, K., \& Crawford, K. (2012). Sexting, consent and young people's ethics: Beyond Megan's Story. Continuum: Journal of Media \& Cultural Studies,
26(3),

463-473.

doi:10.1080/10304312.2012.665840

Asyari, Y. (2017). 2017, Polda Metro tangkap 8 tersangka kasus pornografi anak. Jawapos.com. Diakses dari https://www.jawapos.com/read/2017/09/ 28/159792/2017-polda-metro-tangkap8-tersangka-kasus-pornografi-anak.

Baumgartner, S. E., Sumter, S. R., Peter, J., Valkenburg, P. M., \& Livingstone, S. (2014). Does country context matter? Investigating the predictors of teen sexting across Europe. Computers in Human Behavior, 34, 157-164. doi: 10.1016/j.chb.2014.01.041

Bunardi, M. O. (2015). Perancangan komunikasi visual kampanye anti sexting "rethink" (Master's thesis). Universitas Bina Nusantara, Jakarta.

Crofts, T., Lee, M., McGovern, A., Milivojevic, S. (2017). Sexting pleasures: young people, romance and child pornography (Forthcoming). In C. Driscol, L. Grealy (Eds.). Youth and technology: Pleasure and governance. United Kingdom: Routledge.

Delevi, R., \& Weisskirch, R. S. (2013). Personality factors as predictors of sexting. Computers in Human Behavior, 29, 2589-2594.

Dir, A. L., Ayca, C., Jennifer, L. S., \& Melissa, A. C. (2013). Understanding differences in sexting behaviors across gender, relationship status, and sexual identity, and the role of expectancies in sexting. Cyberpsychology, Behavior, and Social Networking, 16(8), 568-574. doi:10.1089/cyber.2012.0545 
Dir, A. L., Cyders, M. A., \& Coskunpinar, A. (2013). From the bar to the bed via mobile phone: A fi rst test of the role of problematic alcohol use, sexting, and impulsivity-relad traits in sexual hookups. Computers in Human Behavior, 29(4), 1664-1670.

Duncan, S. (2010). A legal response is necessary for self-produced child pornography: A legislator's checklist for drafting the Bill. Oregon Law Review, 89(2), 645-699.

Gordon-Messer, D., Bauermeister, J. A., Grodzinski \& Zimmerman, M. (2013). Sexting among young adults. Journal of Adolescent Health, 52, 301-306.

Guindon, M. H. (2010). Self-esteem across the lifespan: Issues and interventions. USA: Taylor and Francis Group, LLC.

Guindon, M. H. (2010). What is self-esteem. Dalam M.H. Guindon, (Ed.), Self-esteem across the lifespan: Issues and interventions. New York: Routledge.

Hudson, H. K. \& Fetro, J. V. (2015). Sextual activity: Predictors of sexting behaviors and intentions to sext among selected undergraduate students. Computers in Human Behavior, 49, 615-622. doi: 10.1016/j/chb.2015.03.048

Jenaro, C., Flores, N., Gómez-Vela, M., González-Gil, F., \& Caballo, C. (2007). Problematic internet and cell-phone use: Psychological behavioral, and health correlates. Addiction Research \& Theory, 15, 309-320. doi:10.1080/16066350701350247

Lee, C., Moak, S., \& Walker, J. T. (2016). Effect of self-control, social control, and social learning on sexting behavior among South Korean Youths. Youth \& Society, $\quad 48(2), \quad 242-264$. doi:10.1177/0044118X13490762

Lee, M., \& Crofts, T. (2015). Gender, pressure, coercion and pleasure: untangling motivations for sexting between young people. The British Journal of Criminology, 55(3), 454-473.

Lee, M., \& Crofts, T. (2013). Gender, pressure, coercion and pleasure: untangling motivations for sexting between young people. Brit. J. Criminology, 55, 454-473. doi: 10.1093/bjc/azu075

Lenhart, A. (2009). Teens and sexting: how and why minor teens are sending sexually suggestive nude or nearly nude images via text messaging. Pew Internet \& American Life Project, 1-16.

Leung. (2007). Leisure boredom, sensation seeking, self-esteem, addiction symptoms, and patterns of mobile phone use. Mediated Interpersonal Communication, 1-36.

Leung, L. (2008). Linking psychological attributes to addiction and improper use of the mobile phone among adolescents in Hong Kong. Journal of Children and Media, 2(2), 93-113. doi:10.1080/17482790802078565

Lippman, J. R., \& Campbell, S. W. (2012). Teenagers and sexting: perceived norms and sexual double standard. ICA Conference, 24-28 May 2012, Phoenix, AZ.

Lippman, J. L., \& Campbell, S. W. (2014). Damned if you do, damned if you don't...if you're a girl: Relational and normative contexts of adolescent sexting 
in the United States. Journal of Children and Media, 8(4), 371-386. doi:10.1080/17482798.2014.923009

Papalia, D. E., \& Martorell, G. (Eds.13). (2017). Experience human development. New York: McGraw-Hill.

Parker, T. S., Kristyn, M. B., Martha, S. P., \& Jillian, M. H. (2012). Sexting as an intervention: Relationship satisfaction and motivation considerations. The American Journal of Family Therapy 41(1), $1-12$. doi:10.1080/01926187.2011.635134

Rahardjo, W., Hapsari, I., \& Saputra, M. (2014). Kecenderungan mencari sensasi seksual, sexting, dan perilaku seks berisiko pada pelaku sexting tipe twoway sexters. Jurnal Psikologi Indonesia, 11(1), 66-75.

Rahardjo, W., Maizar, S., \& Indria, H. (2015). Harga diri, sexting dan jumlah pasangan seks yang dimiliki oleh pria lajang pelaku perilaku seks beresiko. Jurnal Psikologi, 42(2), 101-114.

Renfrow, D. G., \& Rollo, E. A. (2014). Sexting on campus: Minimizing perceived risks and neutralizing behaviors. Deviant Behavior, 35, 903920. doi: 10.1080/01639625.2014.897122

Rice, P. (1981). The adolescence development. Boston: Allyn and Bacon.

Ricketts, M. L., Maloney, C., Marcum, C. D., \& Higgins, G. E. (2014). The effect of internet related problems on the sexting behaviors of juveniles. American Journal of Criminal Justice, 40(2), 9-15. doi: 10.1007/s12103-014-9247-5
Ringrose, J., Harvey, L., Gill, R., \& Livingstone, S. (2013). Teen girls, sexual double standards and 'sexting': gendered value in digital image exchange. Feminist Theory, 14, 19.

Santrock, J. W. (Eds.13). (2012). Life-span development. University of Texas: Mc Graw-Hill.

Scholes-Balog, K., Francke, N., \& Hemphill, S. (2016). Relationships between sexting, self-esteem, and sensation seeking among Australian young adults. Sexualization, Media, \& Society, 1-8. doi: $10.1177 / 2374623815627790$

Shaughnessy, K., Byers, E. S., \& Walsh, L. (2011). Online sexual activity experience in heterosexual students: Gender similarities and differences. Archives of Sexual Behavior, 40, 419427.

The National Campaign to Prevent Teen and Unplanned Pregnancy. (2008). Sex and Tech: Results from a Survey of Teens and Young Adults. Washington, DC: Author.

Vanden Abeele, M., Roe, K., \& Eggermont, S. (2012). An exploration of adolescents' sexual contact and conduct risks through mobile phone use. Communications, 37, 55-77.

Van Ouytsel, J., Ponnet, K., \& Walrave, M. (2014a). The associations between adolescents' consumption of pornography and music videos and their sexting behavior. Cyberpsychology, Behavior, and Social Networking, 17, 772-778.

Van Ouytsel, J., Van Gool, E., Ponnet, K., \& Walrave, M. (2014). Brief report: The 
association between adolescents' characteristics and engagement in sexting. Journal of Adolescence, 37, 1387-1391.

Van Ouytsel, J., Van Gool, E., Ponnet, K., \& Walrave, M. (2014b). Brief report: The association between adolescents' characteristics and engagement in sexting. Journal of Adolescence, 37, 1387-1391.

Van Ouytsel, J., Van Gool, E., Walrave, M., Ponnet, K., \& Peeters, E. (2016). Sexting: adolescents' perceptions of the applications used for, motives for, and consequences of sexting. Journal of Youth Studies, 1-26. doi: 10.1080/13676261.2016.1241865

Van Ouytsel, J., Walrave, M., Ponnet, K., \& Heirman, W. (2014c). The association between adolescent sexting, psychosocial difficulties, and risk behavior: Integrative review. The Journal of School Nursing, 1, 1-16.

Van Ouytsel, J., Walrave, M., \& Van Gool, E. (2014d). Sexting: between thrill and fear-How schools can respond. The Clearing House: A Journal of Educational Strategies, Issues and Ideas, 87, 204-212.

Wachs, S., Wright, M. F., \& Wolf, K. D. (2017). Psychological correlates of teen sexting in three countries: Direct and indirect associations between selfcontrol, self-esteem, and sexting, International Journal of Development Science, 11, 109-120.
Walker, S., Sanci, L., \& Temple-Smith, M. (2013). Sexting: young women's and men's views on its nature and origins. The Journal of adolescent health: official publication of the society for adolescent medicine, 52, 697-701.

Walrave, M., Wanness, H., \& Lara, H. (2014). Under pressure to sext? Applying the theory of planned behavior to adolescent sexting. Behaviour \& Information Technology, 33(1), 86-98.doi: 10.1080/0144929X.2013.837099

Weisskrich, R., \& Delevi, R. (2011). "Sexting", and adult romantic attachment. Computers in Human Behavior, 27, 1697-1701.

Yeung, T. H., Horyniak, D. R., Vella, A. M., Hellard, M. E., \& Lim, M. S. C. (2014). Prevalence, correlates and attitude towards sexting among young people in Melbourne, Australia. Sexual Health, 11, 332-339. doi: 10.1071/SH14032

Zuckerman, M. (1979). Sensation seeking: Beyond the optimum level of arousal. Hillsdale, NJ: Lawrence Erlbaum Associates.

Zuckerman, M. (1991). Psychobiology of personality. Cambridge: Cambridge University Press.

Zuckerman, M. (1994). Behavioral expressions and biosocial bases of sensation seeking. New York: Cambridge Press. 